\title{
New science plans provoke UK government hostility
}

\section{- BNSC's space plan too ambitious Value-for-money assessment needed}

London

THE British government is seriously questioning the principal findings of two major reviews in science which could mean a rejection of their recommendations. Both the 15-year space plan and the blueprint to strengthen the British information technology industry are under fire from the Cabinet Office, which considers the schemes in part too ambitious or irrelevant.

The space plan argues that Britain must immediately invest $£ 200$ million a year twice the present budget - to meet existing international commitments, principally collaborations involving other members of the European Space Agency (ESA). The Cabinet Office, whose scientific advisers seem to be an important influence in moulding government policy in science, now favours a more phased all been allocated.

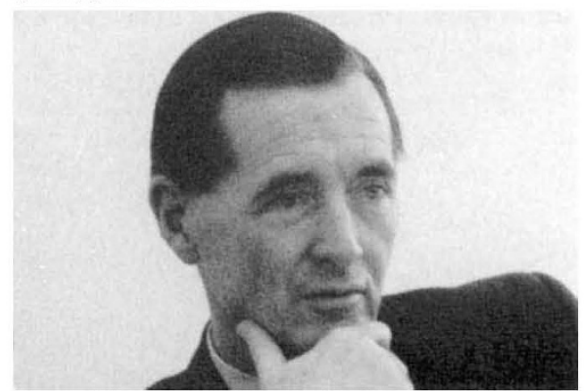

Roy Gibson, head of BNSC, wonders how much he will be able to spend this year.

approach to the space plan under which the recommended yearly expenditure will be reached within three years.

Officials at the British National Space Centre (BNSC), the authors of the space plan, have become embarrassed as the government has failed to respond to the recommendations, delivered last summer. The embarrassment has become acute in the past two months as the officials, now meeting their European colleagues every week, are unable to commit Britain to any new project. Rejection of the plan will mean that BNSC must devise another, although it is becoming clear that little new money, if any, will be available.

A similar fate seems to have befallen the Bide report, prepared by a 21 -strong team of industrialists and academics, led by the ex-chairman of Glaxo, Sir Austin Bide, and submitted to the government last November. The committee (called the IT86 committee) devised a strategy to continue the work of the Alvey research programmes, whose $£ 350$ million (about $£ 200$ million from government coffers) has
The committee recommended that the government should spend $£ 500$ million on new research programmes that would act as catalysts in attracting the same amount from industry. The Cabinet Office is unhappy about the report and seems to want some evaluation on previous Alvey research projects before any new financial commitment is made by government.

But the rejection of these plans, at least in part, will be seen by many as the latest examples of the government's reluctance to spend money on any significant scale.

The government's intransigence was challenged last week by the campaigning society Save British Science (SBS), whose membership is composed of about 700 prominent British scientists. According to the society, at least those research proposals put in the alpha class by the research councils must be supported, if only to restore the confidence of researchers. That would require an investment of some $£ 100$ million a year "for the immediate needs of top quality research"

In a letter to Mr Kenneth Baker, Secretary of State for Education and Science, Professor Joseph F. Lamb, chairman of SBS, emphasized the need. He wrote that "to restore, confidence the government must also announce a long-term policy of increased investment in civil science and technology. The case is urgent, we call upon the government to act without delay."

One report, however, has found favour with the Cabinet Office, that produced by the House of Lords Select Committee on Science and Technology and published on 8 January. While concluding that "neither government nor industry is spending enough at present levels to restore the UK's industrial position and markets", it did not recommend a particular figure for new investment in science. One of its principal recommendations is the creation of a minister at cabinet level, to coordinate research and development policy, and a Council on Science and Technology, to be chaired by the Prime Minister.

The idea of a council is well regarded in the Cabinet Office, which is keen on creating such a body, with members culled from industry, academic institutions, the financial world and government, to devise priorities in research and to ensure that current spending is cost-effective. The government is expected to respond to the Lords report by the spring.

Bill Johnstone

\section{Layfield gives approval to Sizewell B} London

BrItaIN's proposed $£ 1,300$ million pressurized water reactor (PWR) to be based at Sizewell in Suffolk and planned to be the forerunner of five similar complexes thoughout the United Kingdom, has been recommended in the report* of the official inquiry, despite unanswered questions on safety. The report, prepared by Sir Frank Layfield who headed the study, was published this week and details the evidence submitted during the $\mathbf{3 4 0}$ days of the inquiry which closed in the spring of 1985 and in total has cost more than $\mathfrak{£ 3 . 7}$ million.

While the report firmly concludes that "on economic grounds alone, the project should go ahead", it continues: "The examination of safety was not exhaustive. The most important safety problems, and those which cause particular public anxiety, were examined in depth. But many matters were examined only briefly if at all, and much work remains to be done on aspects of the safety case ... Furthermore, the design was incomplete and not yet susceptible to a final assessment of its safety".

For those reasons, claimed Layfield, he "must place a great deal of reliance" on the evidence and promises of the Central Electricity Generating Board (CEGB), which will operate the reactor, and the Nuclear Industry Inspectorate (NII), the safety watchdog of the industry. Layfield claims that they can provide a "continuing assurance of safety". This conclusion is likely to provoke criticism from those who submitted evidence to the inquiry questioning claims made by CEGB and NII.

Since completion of the inquiry, the accident at Chernobyl has heightened public awareness of the dangers. An accident at Sizewell B would have "tolerable" consequences, says Layfield. "Theoretically possible accidents which could cause hundreds or thousands of deaths would almost certainly not occur."

Layfield remains confident that within his best estimate only "one or two workers" at the reactor would die of radiationinduced cancers and that there would be no radiation-induced hereditary diseases.

The economic case for the reactor is fully supported by the Layfield study, as it dismisses the case for an alternative to nuclear energy, principally coal. "The probability of a coal station having lower costs is remote", concludes Layfield. Bill Johnstone

* See page 378 for more on Sizewell. The 'Summary of Conclusions and Recommendations' of the Sizewell B Public Inquiry costs $£ 4.95$ from HMSO. The whole report, in 8 volumes, costs $£ 30$. 